\title{
City and Urban Social Justice, Analyzing and Evaluating Regional Inequalities (Case Study: Eight Urban Deteriorated Districts of Zahedan City)
}

\author{
Fereshte Sheybani Moghadam ${ }^{1}$, Behrouz Darvish ${ }^{1} \&$ Tayebeh Sargolzaee Javan ${ }^{2}$ \\ ${ }^{1}$ Faculty of Human istic and Social Sciences, Science and Research Branch, Islamic Azad University, Tehran, \\ Iran \\ ${ }^{2}$ University of Sistan and Baluchestan, Iran \\ Correspondence: Fereshte Sheybani Mogham, Faculty of Humanistic and Social Sciences, Science and Research \\ Branch, Is lamic Azad University, Tehran, Iran.
}

Received: March 21, 2016 Accepted: July 1, 2016 On line Published: July 31, 2016

doi:10.5539/jpl.v9n6p112 URL: http://dx.doi.org/10.5539/jpl.v9n6p112

\begin{abstract}
Dis solution of distribution system of urban services centers has been one of the most important consequences of the rapid growth of urbanization and physical development of Iranian cities within recent decades. It has brought about social inequalities for citizens in terms of taking advantage of such services. The public urban services forms the physical, social and spatial nature of a city; hence, unfair distribution of such services will impose an irrecoverable influence on both the structure and nature of the city and class-based segregation of districts of the city on the one hand and has brought about serious challenges for the urban management. This study tries to explain life quality levels in the urban deteriorated fabric of Zahedan City based on 38 life quality indexes and their relationship with the urban land uses per capita across different districts; 10-use per capita has been used. Over-18-year-old citizens living in deteriorated districts of Zahedan City constitutes population of this study. Totally 258789 people live in such districts. A total of 384 people were selected as the sample of the study using random sampling and Cochran's formula. A descriptive-analytical method was followed to conduct the study. Initially, exploratory studies and preliminary visits were arranged and then it was followed by the field study, using survey method. Entropy and COPRAS methods were used to determine the sample size of the questionnaires given population of each district and finally to analy ze and rank districts. The results showed that per capita distribution of urban services across the districts 4, 3 and 5 was better than the standard per capita is sued by the Ministry of Housing and Urban Development and they were closer to the ideal con dition. However, there was a large gap between distribution per capita in districts 2, 1, 7 and 8 and the standard per capita and the positive ideal and they have not ideal condition. According to the life quality indexes, accessing to primary schools is the most important item for the citizens and this ite $\mathrm{m}$ is not ideal in these districts and is the first item in the urban services accessibility indexes. Finally, the results of rating districts based on urban per capita and life quality indexes ind icate that there is a weak relationship between urban per capita and life quality indexes; as only a district out of eight ones showed an equal rate.
\end{abstract}

Keywords: social justice, urban services, life quality, per capita, Entropy, COPRAS model, Zahden City

\section{Introduction}

Most social justice theories are based on the fact that social and economic inequity of a society can affect its spatial organization and also any alteration in both spatial organization and socioeconomic relations and income distribution are directly effective in the society (Harvey, 1998: 112). In our time, the most important cause crises in the human societies is rooted in the social inequalities and lack of justice; as the Great Prophet of Islam (PBUH) says, "Monarchy may survive where there is infidelity, but oppression will ruin it." If in a society there is a wide gap between the rich and the needy, in a way that people feel relative deprivation and/or distributive injustice and fail to meet their stimulated needs, so, the socioeconomic system and the state as a whole will soon decline (Hobabi et al. 2011: 104). In general, social justice tries to develop a fair society which relies on equity and cohesion principles and understanding of human rights' values and recognizes dignity and value of each human being (Zajda et al., 2006: 22). Since balanced spatial distribution of urban services is of the most 
important signs of the social justice in a city, social justice in a city means continuance of respecting interests of various social classes based optimal extension of urban resources, incomes and expenses (Gary, 2002: 27). What is important in fair distribution of facilities, as a strategy to realize social justice) is how services and capabilities are distributed among various districts and areas of a city (Harvey, 2000: 97). Therefore, social justice in a city is a synonym of fair spatial distribution of facilities and resources among different areas of the city and people's access to them (Sharifi, 2006: 6). As a result, the most important mission of urban planners and managers is endeavor to access the ideal of "equal opportunities" in terms of accessibility of various groups of the urban society to social services and removing any conflict in providing equal educational, health, service, etc. opportunities. To do so, meeting equity principles and equal access to urban biologic opportunities are among the key prio rities (Hataminejad et al. 2008: 88).

Richardson believes that "equity" is a complicated and confusing concept. "Equity" shall be mentioned, however explaining it deeply is impossible, because its explanation in philosophy and ethics has ended in stalemate. Hudson refers to three faces of equity: equality of income, equal reward for effort, and the distribution impact of the supply of public services. The first face is the aim and ideal of an egalitarian society. The second one emphasizes the equality of opportunity rather equality of income and provides a rationale for the market economy. While the third is important but it disguises its influence on equity in mixed economies (Richardson, 1979: 161). Numerical equity, or horizontal equity, is called by some authors as the equal access to the public services (Davas et al., 1993: 111). Generally, regarding urban development considerations, justice covers certain concepts such as proper distribution of functions and services, proper access to service and activity centers without any discrimination and difference among residents of a city or an urban district. Hence, the world in which we live today is a Cosmo polis whose consequence sadly is separation from the natural environment and recognizing unwanted imbalances which are rooted in unbalanced human relations and urban spaces. Today, most people feel that urban districts are improper and poor for living and working, because population growth and rapid trend of urbanization within previous decades have been followed by negative consequences including unbalanced physical distribution of cities, development of marg inal neighborhoods, poverty and collapse of the life standards, lack of service centers and finally inequity in using facilities (Taghvaie and Kiomarthi, 2011: 24). Hence, optimal distribution of facilities and services necessary for citizens across the city in a way that all citizens can access them properly is very essential because meeting citizens' needs and minimizing their unnecessary movements and trips will save their time and costs, which in turn will result in urban sustainability (Maleki, 2003: 37). Inequity and lack of spatial balance in residents of various districts of a city is not a new phenomenon and can be found in all cities in the world. However, since socioeconomic differences and unfair and unbalanced distribution of services is clear cut in the developing countries, the spatial difference of cit ies has been exacerbated (Mobaraki and Abdoli, 2013: 50).

In Iran, the urban centralization trend, which had been started after land reforms of 1960's, was accelerated after the Iran-Iraq War. And it doubled lack of urban facilities and infrastructures while the urban population was increasing (Hatamainejad et al. 2012: 43). Iran, like most other developing countries, suffers from a wide gap between its districts in terms of enjoying of development resources including urban services index, as a major component. In Iran, different urban classes, regarding their life quality, have different access to such services and facilities (A manpour et al. 2013: 108). Zahden City with a very short history of urbanization has experienced an unbalanced growth during recent decades. The urban inequalities in this city have been deteriorated as the result of the unbrid led immigration of villagers, an unplanned growth of the city and inefficient management, as today we see social inequalities in terms of distribution of public services among citizens and urban areas.

\section{Theoretical Basics}

Principally, the concept of social justice is not comprehensive to the extent that can be used as a way to judge about the welfare level of a society. Basically, justice can be considered as a major title which has been developed to settle down conflicts. Social justice actually is application of these certain principles (Kalantary et al. 2013: 14). Social justice is posed in the urban space when one talks about meeting needs of all urban residents in an equal way; so, underestimating social justice would be followed by unpleasant consequences such as marg inalization and excessive density in a single district, unilateral development of cities, evacuation of s ome urban areas, speculation and tends other problems. Thus, identification of social justice influences is the fundamental part of the urban studies and a city will be a human city when all of its aspects are covered by the social justice (Khoshroi, 2006: 12). Paying attention to social justice is somehow important in cities; with it plays a key role in all determinant indexes of healthy cities (Sheikhi, 2001: 264). Proper and optimal distribution of social, economic, cultural and sanitary facilities among various areas and regions is one of the most important factors for preventing inequalities and gap of spatial development and distribution. In scientific discussions, 
paying attention to the principle of fair distribution of facilities and infrastructures is very important. In many developing countries, quick and unbalanced growth has exacerbated regional dispersions and underdevelopment level of different parts of the society. In the unbalanced development process, a few growth centers are developed near extensive underdeveloped districts and areas, but because of their differences with the local technology and expertise level, they cannot be published and actually the unbalanced development process is recreated continuously. Many studies show that inattention to principles of the balanced development can pave the way for occurrence of several social harms in the underdeveloped areas and prevent economic growth in the whole society. Unbalanced development process can exacerbate immigration which in turn brings about many other problems. Therefore, justice in cities needs to assign proper facilities and services, to use potential and practical abilities in cities, to remove the wide gap between the needy and the rich and to prevent poor slums. As a result, any type of urban planning based on social justice in city must be effective either in distribution or allocation of needs, public interests. Using spaces and proper distribution, or in better words spatial justice, is one of the most important factors in the urban planning. Distribution pattern of urban services centers has brought about a different value for the urban lands and has exacerbated segregation of human groups. Always there has been a rotational relation between spatial inequalities and unfair distribution of services and environmental and physical problems across the city which support each other and will make the city an unlivable place by increasing the population and stimulating both horizontal and vertical extension; as today many current problems of cities can be rooted in the former unfair distribution of urban services. Inequity and lack of spatial balance in residents of various districts of a city is not a new phenomenon and can be found in all cities in the world. However, since socioeconomic differences and unfair and unbalanced distribution of services is clear cut in the developing countries, the spatial difference of cities has been exacerbated (Abdi Daneshpour, 2009: 37); because spatial structure of a city is composed of elements and factors that which interact, so instability of each element will affect the whole structure (Sauj and Ward, 2001: 90).

\subsection{Popular Perspectives about Urban Space and Social Inequalities}

A) Functionalis m perspective on space and social inequity

Functionalism perspective on social inequity in the urban geography has been mostly posed by ecologists. In this school, Ernest Hockle's plant ecology theory has been applied to the social life of city; because founders of Chicago School believes that urban groups, apart from their social, economic and ethnic roots, like plan species, moves toward balance and experience their all ecologic stages in their own habitate over time (Shokohi, 2000: 127). Functionalists conclude from global and eternal aspect of inequity that inequity is the key part of each social organization and is a functionalist necessity which helps the society to have an effective function. Davis and Moore provide two major standards for the functional significance of a situation: a) How rare is the situation rather other situations, and b) how much other situations depend on the situation in question. For them, social inequity is an unconscious design by which societies make sure that the most important situations will be occupied by the best people consciously (Afrough, 1999: 172).

B) Power in space and social inequity perspective

For Marx, social class is formed based on various situations and duties people have in the society's production structure. Two main factors are involved with formation of social class: production style (agriculture, crafts and industry) and relations of production. For Marx, having different situation in terms of tools of production differentiates people (Tamin, 1994: 6).

For Marx and Engels an urban space was a territory in which enweaved process of capital accumulation and class conflicts are concentrated. In large cities trade, factory productions, ownership concentration and population density reach their highest level and finally we have a rich class and a poor class. In cities, capital concentration and polarization of social classes is realized and extended. In general, there are two particular points in Marx perspective which helps to form a relationship between space and social inequity. First, his view to city after development, accumulation and concentration of capital; second, paying attention to....... as a field of ecologic concentration of proletariat and as a result emergence of class self-aware is considered as a significant factor in formation of classes (Hatamine jad et al. 2008: 74).

Unlike the Marx interpretation of emergence of inequity based on the economic aspect, which was the most important foundation of the social life for him, Marx Weber believed that offering a unilateral interpretation for a complicated social phenomenon like social inequities makes it less important (Kamali, 2000: 108).

\section{Methodol ogy}

A descriptive-analytical method was followed to conduct the study. "Survey" technique was used to collect data. 
Over-18-year-old citizens living the in deteriorated districts of Zahedan City constitutes population of this study. Totally 258789 people live in such districts. A total of 384 people were selected as the sample of the study using random sampling and Cochran's formula (Hafeznia, 2012: 167). Initially, the urban functions were extracted from the detailed and the comprehensive plans and then library and survey techniques were used to elicit life quality inde xes. Data were analy zed using explanatory and quantitative methods. Entropy was used in this study for weighting (Sudhira et al, 2003: 24) and COPRAS model was used to evaluate and to rank capitas and also to evaluate life quality indexes. Indexes of the study were grouped into four classes. Each question of questionnaire was provided with five choices, "very high", "high", "medium", "low", and "very low", in order to co mpare the availability of life quality indexes in various districts. In this study 1, 2, 3, 4, and 5 weights were considered. The necessary information about urban capita of each function across districts was extracted from comprehensive and detailed plans. Then, standard capitas for each function, suggested by the Ministry of Housing and Urban Development, were extracted and the results of districts were compared with the standard and positive ideal capita.

\section{COPRAS Model}

Multiple-criteria decision-making (MCDM) which are usually referred as multipurpose decision making models and multi-criteria analysis (MCA) models are as set of techniques which allow decision makers, considering a set of (mostly contradicted) criteria, to select, rank, arrange and/or describe a set of choices in decision making process (Chandra Das et al, 2012: 234). Each model has certain features as well as advantages and disadvantages. MCDMs are proper for evaluating life quality in the deteriorated fabric areas. Most multi-criteria models need to define a quantitative weight to evaluate relative significance of different criteria (Cheng, 2000: 5). All multi-criteria decision making models have three stages as follows:

1) Determining proper choices and criteria

2) Measuring relative significance of each criterion and effects of such choices on criteria

3) Calculating nu merical values to set rank of each choice (Kakalauskas et al, 2009: 460).

Many special models have been proposed for multi-criteria decision makings, which have advantages and constraints (Pourtaheri et al., 2011: 37). The most important features of the COPRAS Model in contrast to other MCDMs are: 1) It is clear that this model is simpler and it needs shorter time to complete its calculations in contrast to other models such as AHP and TOPSSIS. 2) COPRAS is able to propose a complete and perfect ranking of choices. 3) This model is able to use both qualitative and quantitative criteria to calculate criteria. 4) COPRAS is able to calculate positive (maximum) and negative (minimum) criteria separately in the evaluation process. 5) Another important feature of COPRAS which makes it a better option rather other decision making models is that it can estimate significance of each choice and to show it in percentage (Muliner et al. 2012: 5). Various phases of COPRAS Method are as follows:

First and second phases: Formation of the status quo matrix based on the designed criteria and measuring weight of each criterion based on one of weighting methods.

Third phase: Normalizing the decision making matrix

$$
\operatorname{dij}=\frac{q i}{\sum_{j=1}^{n} x i j} x i j
$$

Where qi is the weight of ith criterion and xji is value of each choice per each criterion

$$
\sum_{j=1}^{n} d i j
$$

Fourth phase: Calculating the sum weight of the normalized criterion. It describes alternatives which are measured with positive criteria and are shown with $\mathrm{sj}+$ and alternatives with are measured with negative criteria and are shown with sj-. The following equation is used to calculate them.

$$
S j^{+}=\sum_{z i}=^{+} d i j \quad S j^{-}=\sum_{z i}=^{-} d i j
$$

Fifth phase: Comparative ranking of alternatives which is calculated based on positive and negative criteria. Relative significance qi of each alternative $\mathrm{Aj}$ is measured using the following equations: 


$$
Q_{j}=S_{j}^{+}+\frac{S_{\text {min }}^{-} \sum_{j}^{n}=1 S_{j}^{-} x}{S_{j}^{-} \sum_{j}^{n}=1 \frac{S_{\text {min }}^{-}}{S_{j}^{-}}}=S_{j}^{+}+\frac{\sum_{j}^{n}=1 S_{j}^{-}}{S_{j}^{-} \sum_{j}^{n}=1 \frac{1}{S_{j}}}+\cdots
$$

Sixth phase: Prioritizing alternatives based on qi; hence, the larger qi, the higher will be the ranking of the alternative in the prioritization. in this case, the alternative with the best possible condition or in other words, an ideal alternative always has the highest value (Ku mar Dey et al; 2011: 571).

Seventh phase: The final phase is determining the alternative which has the best condition in terms of criteria; when rank of an alternative in increased or decreased, its significance will be increased or decreased. Alternatives which have had the best condition in terms of criteria are marked with the highest significance degree $\mathrm{N}_{\mathrm{j}} ; \mathrm{N}_{\mathrm{j}}$ is equal to $100 \%$. Total value of significance degree of each criterion is calculated and it varies from 0 to 100 and the best and worst alternatives are determined in this range. Significance degree of each $\mathrm{N}_{\mathrm{j}}$ of alternative $A_{j}$ is calculated by the following equation:

$$
N_{j}=\frac{Q_{j}}{Q_{\max }} \times 100
$$

Where, Qi is the significance degree of each alternative and $\mathrm{Q}_{\max }$ is the highest amount that an ideal alternative has assigned to itself (anucheviciene et al; 2011: 322).

Life quality evaluation model in deteriorated fabric areas of Zahden City

As figure 1 shows the following variables were used for evaluating life quality of citizens of Zahedan City. In this study, urban life quality is considered as a dependent variable and physical, environmental, social and accessibility to urban services criteria are considered as independent variables. 


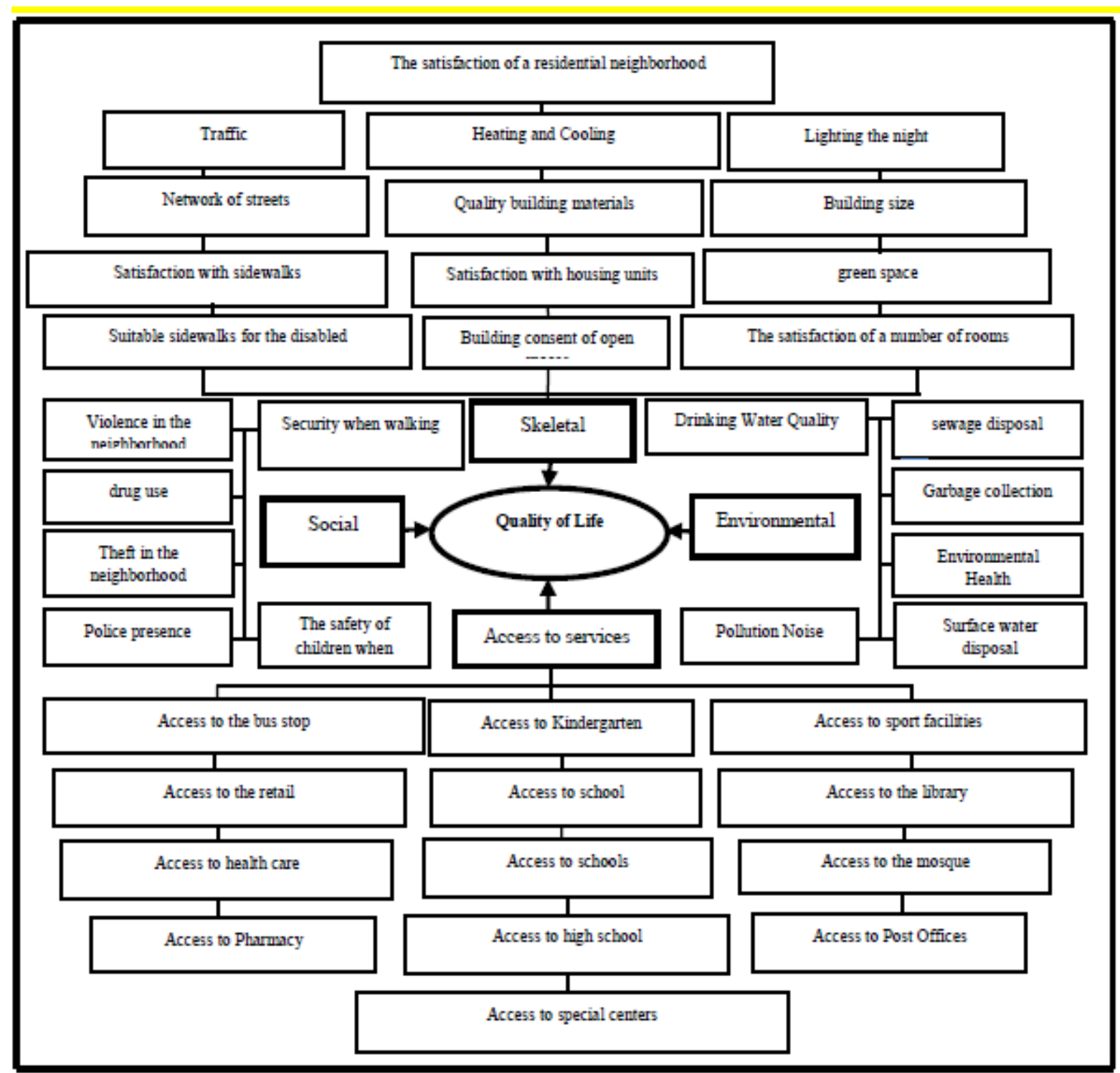

Figure 1. Analytical model of the effective criteria of citizens' life quality in the deterio rated fabric areas of Zahedan

Source: Field studies the authors, 1394.

\section{Territory}

Zahedan city is the capital city of Sistan-Baluchestan Province, eastern Iran, near the border between Iran and Afghanistan and Pakistan. This city is the center of Zahedan County (Fig. 2). Since this city is a main destination for most immigrations in various periods, today it suffers from an extensive marginalization which has made social and economic development in this city problematic, as it is considered as one of deprived cities of Iran in terms of accessibility to welfare facilities and services for the residents. The border nature of the city, cultural similarities with Afghanistan and Pakistan, commodity and drug transit line have deprived the city from the effective potentials on the city's life quality; as most domestic and foreign immig rants of the city have forced to live in marginal areas and slums of the city because of financial problems. These areas are found in northern and northeastern parts of the city (Ebrahimzadeh, 2004: 127). 


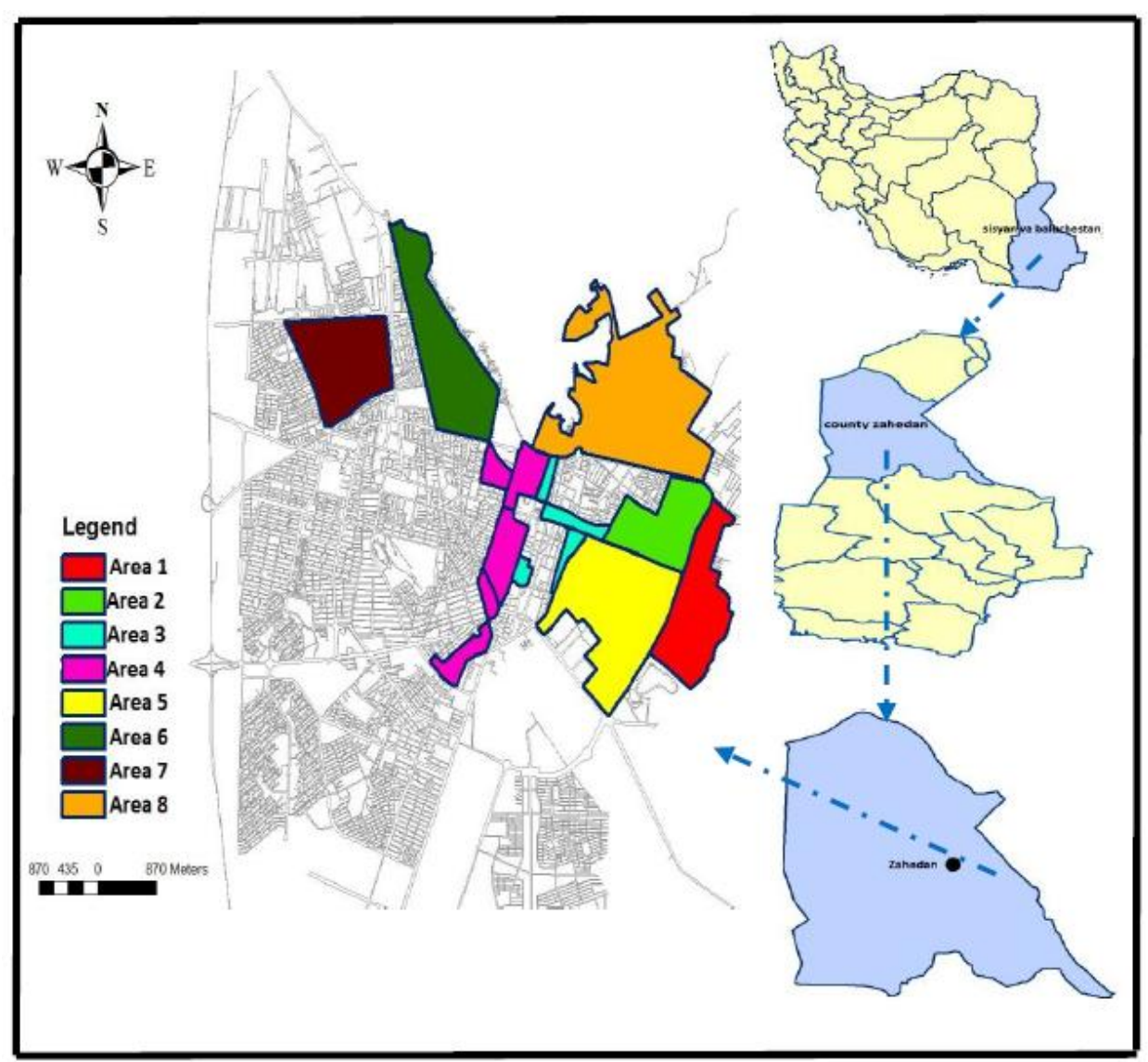

Figure 2. The geographical location of Zahedan

\section{Findings}

This study aimed analy zing how facilities and services have been distributed across the deteriorated fabric areas of Zahedan City; it would help us to understand that how much the urban capita distribution method is compatible with people's content about life quality in such areas. To do so, initially urban capita of the available functions across the deteriorated fabric areas were analyzed using COPRAS Model, which is the first phase in this model.

First phase: Data matrix formation based on $\mathrm{n}$ criteria and $\mathrm{m}$ choices 
Table 1. Distribution of per capita urban matrix in the old texture areas in Zahedan

\begin{tabular}{|c|c|c|c|c|c|c|c|c|c|c|}
\hline 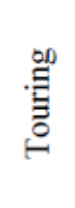 & 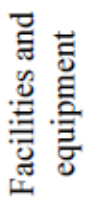 & 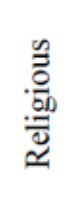 & 哭 & 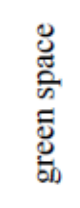 & 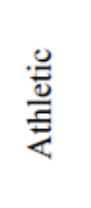 & 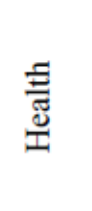 & 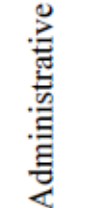 & 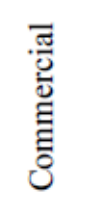 & 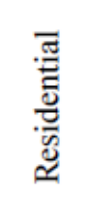 & 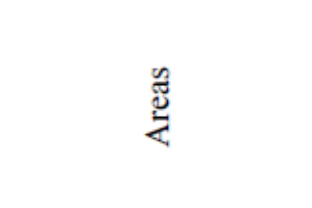 \\
\hline 0 & $0 / 04$ & $0 / 71$ & $1 / 28$ & $0 / 27$ & $0 / 29$ & $0 / 16$ & $0 / 32$ & $0 / 1$ & $24 / 35$ & 1 \\
\hline 0 & $0 / 04$ & $0 / 45$ & $0 / 46$ & $1 / 42$ & 0 & $0 / 19$ & $0 / 01$ & $0 / 06$ & $27 / 23$ & 2 \\
\hline $0 / 06$ & $0 / 43$ & $0 / 48$ & $1 / 32$ & $0 / 96$ & 0 & $1 / 92$ & $0 / 40$ & $1 / 31$ & $32 / 13$ & 3 \\
\hline $0 / 53$ & 0 & $1 / 18$ & $0 / 99$ & $1 / 56$ & 0 & $1 / 19$ & $4 / 47$ & $4 / 26$ & $31 / 00$ & 4 \\
\hline 0 & 0 & $0 / 81$ & $1 / 81$ & $0 / 67$ & 0 & $0 / 94$ & $0 / 86$ & $1 / 03$ & $35 / 75$ & 5 \\
\hline 0 & 0 & $0 / 24$ & $1 / 21$ & $0 / 24$ & $0 / 08$ & $0 / 07$ & $0 / 01$ & $0 / 04$ & $26 / 71$ & 6 \\
\hline 0 & $0 / 28$ & $0 / 31$ & $0 / 33$ & $0 / 55$ & $0 / 59$ & $0 / 27$ & $0 / 05$ & $0 / 44$ & $23 / 82$ & 7 \\
\hline 0 & $0 / 68$ & $0 / 26$ & $0 / 70$ & $0 / 25$ & $0 / 48$ & $0 / 06$ & $0 / 08$ & $0 / 12$ & $24 / 57$ & 8 \\
\hline $0 / 40$ & $5 / 60$ & $0 / 75$ & $4 / 40$ & $9 / 50$ & $2 / 50$ & $1 / 50$ & $2 / 00$ & $2 / 40$ & $30 / 00$ & Standard per capita \\
\hline $0 / 53$ & $0 / 68$ & $1 / 81$ & $1 / 81$ & $1 / 56$ & $0 / 59$ & $1 / 92$ & $4 / 47$ & $4 / 36$ & $35 / 75$ & The highest per capita \\
\hline 0 & 0 & $0 / 24$ & $0 / 33$ & $0 / 25$ & 0 & $0 / 06$ & $0 / 01$ & $0 / 04$ & $23 / 82$ & The lowest per capita \\
\hline
\end{tabular}

As table 1 shows at the highest capita for each function, the highest capita were lower than the standard capita or a little higher. In this regard, the highest capitas belonged to commercial, official, and religious capitas and they were higher than the standard capita, while sport, green space, education, installations and equipment capita were lower than standard capita and it demonstrate how poor are these functions across the deteriorated fabric areas. At the lowest performance of capita, all capitas were lower than the standard level of the suggested capitas which it shows that distribution of functions in the deteriorated fabric areas has been unbalanced and the most difference was seen between distribution of capitas in sport, green space, installations and urban equipment functions; though the difference is considerable in all capitas. In the second phase, after formation of the status quo matrix, in order to normalize the status quo matrix, initially criteria are weighted. In this study, Shannon Entropy was used for weighting.

Table 2. The weight of each per capita across regions distressed areas

\begin{tabular}{|c|c|c|c|c|}
\hline Rank & Weight & $\mathrm{z}$ & Criterion & Row \\
\hline 10 & $0 / 002$ & + & Residential & 1 \\
\hline 5 & $0 / 128$ & + & Commercial & 2 \\
\hline 2 & $0 / 173$ & + & Administrative & 3 \\
\hline 6 & $0 / 081$ & + & Health & 4 \\
\hline 3 & $0 / 133$ & + & Athletic & 5 \\
\hline 8 & $0 / 031$ & + & green space & 6 \\
\hline 9 & $0 / 017$ & + & Training & 7 \\
\hline 7 & $0 / 034$ & + & Religious & 8 \\
\hline 4 & $0 / 131$ & + & Facilities and equipment & 9 \\
\hline 1 & $0 / 270$ & + & Touringiran & 10 \\
\hline
\end{tabular}

Source: authors, 2016.

As table (2) and diagram (1) indicate, residential and educational, green space and relig ious capitas have been distributed more fairly across the deteriorated fabric areas, but other capita, especially Iran touris m, official, sports, facilities and equipment, commercial, sanitary and health have not been distributed across the deteriorated fabric areas of the city. 


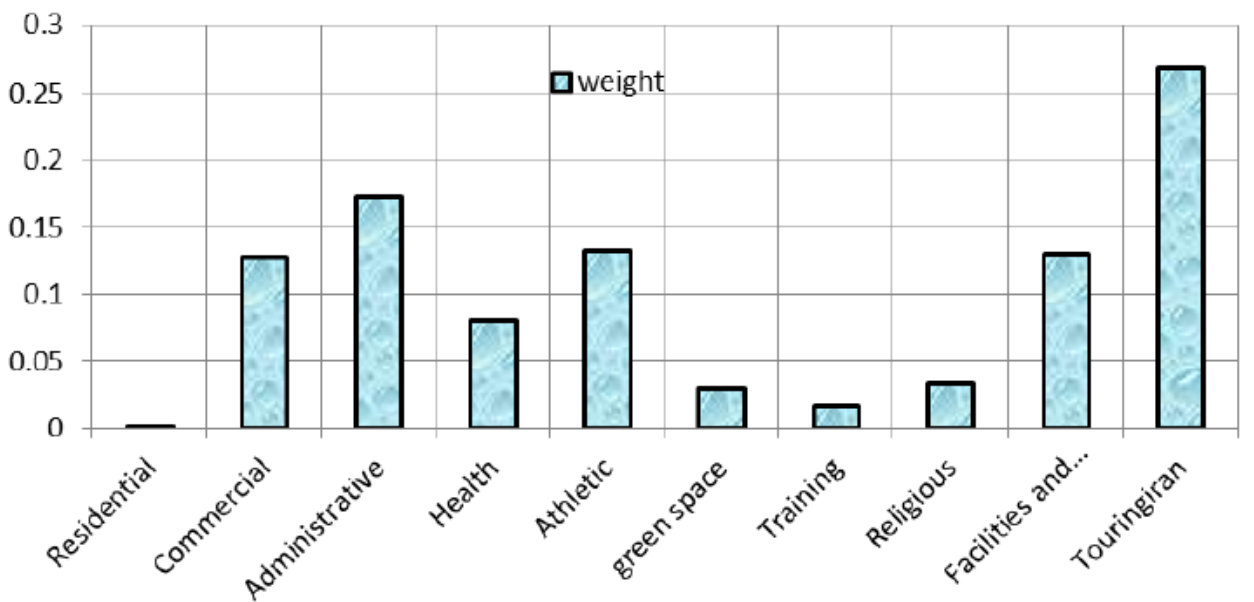

Chart (1) weight each per capita in areas of old ones

Source: authors, 2016.

In the third phase, after calculating the weight of criteria, the status quo matrix is normalized using the following equation:

$$
d i j=\frac{q i}{\sum_{j=1}^{n} x i j} x i j
$$

Table 3. Normalized matrix

\begin{tabular}{|c|c|c|c|c|c|c|c|c|c|c|}
\hline $\mathrm{X} 10$ & $\mathrm{X} 9$ & $\mathrm{X} 8$ & $\mathrm{X} 7$ & $\mathrm{X} 6$ & $\mathrm{X} 5$ & $\mathrm{X} 4$ & $\mathrm{X} 3$ & $\mathrm{X} 2$ & $\mathrm{X} 1$ & Area \\
\hline 0 & $0 / 004$ & $0 / 006$ & $0 / 006$ & $0 / 002$ & $0 / 030$ & $0 / 002$ & $0 / 007$ & $0 / 002$ & $0 / 003$ & 1 \\
\hline 0 & $0 / 004$ & $0 / 004$ & $0 / 002$ & $0 / 010$ & 0 & $0 / 003$ & 0 & $0 / 001$ & $0 / 004$ & 2 \\
\hline $0 / 022$ & $0 / 043$ & $0 / 004$ & $0 / 006$ & $0 / 007$ & 0 & $0 / 028$ & $0 / 009$ & $0 / 019$ & $0 / 005$ & 3 \\
\hline $0 / 190$ & 0 & $0 / 010$ & $0 / 005$ & $0 / 011$ & 0 & $0 / 018$ & $0 / 103$ & $0 / 062$ & $0 / 004$ & 4 \\
\hline 0 & 0 & $0 / 007$ & $0 / 009$ & $0 / 005$ & 0 & $0 / 014$ & $0 / 020$ & $0 / 015$ & $0 / 005$ & 5 \\
\hline 0 & 0 & $0 / 002$ & $0 / 006$ & $0 / 002$ & $0 / 008$ & $0 / 001$ & 0 & $0 / 001$ & $0 / 004$ & 6 \\
\hline 0 & $0 / 028$ & $0 / 003$ & $0 / 002$ & $0 / 004$ & $0 / 061$ & $0 / 004$ & $0 / 001$ & $0 / 006$ & $0 / 003$ & 7 \\
\hline 0 & $0 / 068$ & $0 / 002$ & $0 / 003$ & $0 / 002$ & $0 / 050$ & 0 & $0 / 002$ & $0 / 002$ & $0 / 003$ & 8 \\
\hline
\end{tabular}

Source: authors, 2016.

In the fourth phase, after normalizing the criteria, $\sum \boldsymbol{s} \boldsymbol{j}^{+}$and $\sum \boldsymbol{s} \boldsymbol{j}^{-}$are calculated. To do so, for each choice positive and negative indexes are calculated, separately.

In the fifth phase, QJ is calculated based on positive and negative criteria through the following equation:

$$
Q_{j}=S j^{+}+\frac{S_{\text {min }}^{-} \sum_{j}^{n}=1 S_{j}^{-} x}{S_{j}^{-} \sum_{j}^{n}=1 \frac{S_{\min }^{-}}{S_{j}^{-}}}=S_{j}^{+}+\frac{\sum_{j}^{n}=1 S_{j}^{-}}{S_{j}^{-} \sum_{j}^{n}=1 \frac{1}{S_{j}}}
$$

Final phase: in this phase, the alternative which has the best status among other criteria. The higher the Qi of a choice, its $\mathrm{N}_{\mathrm{j}}$ will be higher, too. It is implied as percentage, it means that its total sum is calculated from 0 to 100 .

$$
N_{j}=\frac{Q_{j}}{Q_{\max }} \times 100
$$

Ranking is conducted based on $Q_{J}$ value; it means that areas with the highest value of $\mathrm{Q}_{\mathrm{j}}$ and $\mathrm{N}_{\mathrm{j}}$ have the highest quality of life. As table (4) shows district 4 has the best quality of life. 
Table 4. The results of the model cooper

\begin{tabular}{|c|c|c|c|c|c|}
\hline Rank & $\mathrm{Nj}$ & $\mathrm{Qj}$ & $\mathrm{Sj}^{-}$ & $\mathrm{Sj}^{+}$ & Area \\
\hline 6 & $15 / 53$ & $0 / 063$ & 0 & $0 / 063$ & 1 \\
\hline 7 & $6 / 91$ & $0 / 028$ & 0 & $0 / 028$ & 2 \\
\hline 2 & $35 / 37$ & $0 / 143$ & 0 & $0 / 143$ & 3 \\
\hline 1 & 100 & $0 / 403$ & 0 & $0 / 403$ & 4 \\
\hline 5 & $18 / 34$ & $0 / 074$ & 0 & $0 / 074$ & 5 \\
\hline 8 & $5 / 80$ & $0 / 023$ & 0 & $0 / 023$ & 6 \\
\hline 4 & $27 / 75$ & $0 / 112$ & 0 & $0 / 112$ & 7 \\
\hline 3 & $32 / 87$ & $0 / 132$ & 0 & $0 / 132$ & 8 \\
\hline
\end{tabular}

Source: authors, 2016.

\section{Analyzing life quality indexes across de teriorated fabric areas}

As mentioned previously, COPRAS model was used to evaluate spatial distribution of life quality indexes across the deteriorated fabric areas in Zahedan City. For analyzing life quality indexes based on citizens' views of all deteriorated fabric areas some inde xes had the highest score and some of the mhad the lowest score.

The first step in this model is offering indexes used in this study which after collecting data through questionnaire and converting them into quantitative data by measuring its values and determining the value of each indexes in each district (in Excel), raw data matrix of each criterion was defined. In this matrix, choices of the deteriorated fabric areas and 38 criteria were determined.

Table 5. Matrix status quo

\begin{tabular}{|c|c|c|c|c|c|c|c|c|c|c|c|c|c|c|c|c|c|c|c|}
\hline $\mathrm{X} 19$ & $\mathrm{X} 18$ & $\mathrm{X} 17$ & $\mathrm{X} 16$ & $\mathrm{X} 15$ & $\mathrm{X} 14$ & $\mathrm{X} 13$ & $\mathrm{X} 12$ & $\mathrm{X} 11$ & $\mathrm{X} 10$ & $\mathrm{X} 9$ & $\mathrm{X} 8$ & $\mathrm{X} 7$ & $\mathrm{X} 6$ & $\mathrm{X} 5$ & $\mathrm{X} 4$ & $\mathrm{X} 3$ & $\mathrm{X} 2$ & $\mathrm{X} 1$ & Area \\
\hline $3 / 8$ & $3 / 55$ & $2 / 67$ & $1 / 49$ & $1 / 59$ & $2 / 22$ & $2 / 18$ & $2 / 08$ & $2 / 27$ & $2 / 94$ & $2 / 78$ & $3 / 27$ & $3 / 86$ & 1 & $1 / 12$ & $1 / 98$ & $2 / 61$ & $1 / 88$ & 1 & 1 \\
\hline $2 / 08$ & $4 / 24$ & $3 / 61$ & $2 / 34$ & $2 / 55$ & $3 / 71$ & $3 / 16$ & $1 / 84$ & $2 / 13$ & $1 / 95$ & $1 / 39$ & $3 / 68$ & $3 / 63$ & 1 & $1 / 82$ & $1 / 21$ & $2 / 03$ & 1 & $1 / 32$ & 2 \\
\hline $1 / 9$ & $3 / 31$ & $2 / 58$ & $1 / 95$ & $3 / 39$ & $2 / 9$ & $3 / 44$ & $1 / 98$ & $2 / 51$ & $2 / 53$ & $2 / 36$ & $3 / 76$ & $4 / 1$ & $1 / 15$ & $3 / 83$ & $2 / 36$ & $3 / 03$ & $2 / 61$ & $1 / 63$ & 3 \\
\hline $1 / 38$ & $4 / 38$ & 4 & $3 / 63$ & $4 / 13$ & $4 / 25$ & $4 / 13$ & $4 / 25$ & $3 / 38$ & $3 / 25$ & 3 & $4 / 5$ & $2 / 88$ & $2 / 88$ & $3 / 88$ & $2 / 63$ & 3 & $2 / 5$ & $2 / 13$ & 4 \\
\hline $1 / 75$ & $3 / 82$ & $3 / 75$ & $2 / 14$ & $2 / 5$ & $3 / 57$ & $3 / 18$ & $4 / 11$ & $3 / 04$ & $4 / 07$ & $3 / 93$ & 4 & $3 / 93$ & $1 / 29$ & $4 / 07$ & $3 / 36$ & $2 / 61$ & $3 / 68$ & $3 / 61$ & 5 \\
\hline $2 / 91$ & $2 / 63$ & $2 / 51$ & $1 / 33$ & $1 / 43$ & $2 / 55$ & $2 / 37$ & $1 / 67$ & $1 / 52$ & $2 / 66$ & $2 / 64$ & $2 / 9$ & $3 / 7$ & 1 & $2 / 48$ & $2 / 19$ & $2 / 31$ & $2 / 06$ & 1 & 6 \\
\hline $1 / 9$ & $3 / 67$ & $2 / 29$ & $2 / 9$ & $3 / 54$ & $3 / 06$ & $2 / 31$ & $3 / 96$ & $1 / 98$ & $2 / 63$ & $2 / 4$ & $2 / 77$ & $3 / 46$ & 1 & 1 & 1 & $1 / 83$ & $2 / 42$ & 1 & 7 \\
\hline $1 / 33$ & $2 / 48$ & $1 / 76$ & $1 / 11$ & $1 / 82$ & $2 / 42$ & $2 / 04$ & $1 / 55$ & $1 / 18$ & $2 / 73$ & $2 / 38$ & $2 / 52$ & $4 / 21$ & 1 & $1 / 9$ & 2 & $2 / 11$ & $1 / 89$ & $1 / 82$ & 8 \\
\hline
\end{tabular}

Continuation table (5)

\begin{tabular}{|c|c|c|c|c|c|c|c|c|c|c|c|c|c|c|c|c|c|c|c|}
\hline $\mathrm{X} 38$ & $\mathrm{X} 37$ & $\mathrm{X} 36$ & $\mathrm{X} 35$ & $\mathrm{X} 34$ & $\mathrm{X} 33$ & $\mathrm{X} 32$ & $\mathrm{X} 31$ & $\mathrm{X} 30$ & $\mathrm{X} 29$ & $\mathrm{X} 28$ & $\mathrm{X} 27$ & $\mathrm{X} 26$ & $\mathrm{X} 25$ & $\mathrm{X} 24$ & $\mathrm{X} 23$ & $\mathrm{X} 22$ & $\mathrm{X} 21$ & $\mathrm{X} 20$ & $\mathrm{Area}$ \\
\hline $2 / 84$ & $2 / 73$ & $2 / 29$ & $1 / 45$ & $3 / 63$ & $3 / 65$ & $2 / 16$ & $1 / 96$ & $2 / 67$ & $3 / 24$ & 3 & $2 / 43$ & $1 / 55$ & $2 / 69$ & $2 / 88$ & 1 & $2 / 31$ & $1 / 98$ & $2 / 14$ & 1 \\
\hline $2 / 26$ & $2 / 05$ & $2 / 05$ & $1 / 39$ & $3 / 13$ & $4 / 05$ & $3 / 05$ & $2 / 92$ & $3 / 61$ & $3 / 82$ & 4 & $2 / 95$ & $2 / 03$ & $3 / 03$ & $3 / 11$ & 1 & $2 / 11$ & $2 / 11$ & $3 / 45$ & 2 \\
\hline $4 / 05$ & $4 / 02$ & $4 / 02$ & $1 / 22$ & $3 / 31$ & $1 / 81$ & $2 / 29$ & $2 / 22$ & $3 / 83$ & $3 / 24$ & $4 / 17$ & $2 / 64$ & $2 / 02$ & $2 / 97$ & $3 / 51$ & $2 / 98$ & $2 / 88$ & $1 / 81$ & $2 / 34$ & 3 \\
\hline $2 / 88$ & $2 / 88$ & $2 / 88$ & $1 / 88$ & $2 / 63$ & $3 / 88$ & $3 / 5$ & $3 / 5$ & $4 / 25$ & $4 / 63$ & $4 / 63$ & $4 / 13$ & $3 / 75$ & $3 / 88$ & $4 / 13$ & 4 & $3 / 25$ & $3 / 63$ & $3 / 75$ & 4 \\
\hline $3 / 46$ & $3 / 5$ & $3 / 29$ & $1 / 21$ & $4 / 18$ & $3 / 64$ & $2 / 82$ & $2 / 82$ & $3 / 54$ & $4 / 14$ & $2 / 07$ & $2 / 71$ & $2 / 75$ & $2 / 43$ & $2 / 93$ & 1 & $2 / 64$ & $3 / 14$ & $2 / 18$ & 5 \\
\hline $2 / 93$ & $2 / 79$ & $2 / 64$ & $1 / 06$ & $3 / 37$ & $2 / 88$ & $1 / 85$ & $1 / 85$ & $3 / 43$ & $3 / 48$ & $1 / 58$ & $2 / 06$ & $1 / 4$ & $1 / 91$ & $3 / 22$ & 1 & $1 / 87$ & $1 / 54$ & $3 / 81$ & 6 \\
\hline $2 / 75$ & $2 / 52$ & $2 / 4$ & $1 / 15$ & $3 / 17$ & $3 / 23$ & $2 / 1$ & $2 / 1$ & $3 / 33$ & $4 / 58$ & $1 / 92$ & $2 / 42$ & $1 / 79$ & $1 / 94$ & $2 / 27$ & $1 / 13$ & $3 / 35$ & $2 / 21$ & $1 / 4$ & 7 \\
\hline $2 / 02$ & $1 / 96$ & $1 / 95$ & $1 / 02$ & $2 / 9$ & $1 / 97$ & $1 / 42$ & $1 / 42$ & $2 / 85$ & $3 / 11$ & $1 / 73$ & $2 / 15$ & $1 / 2$ & $1 / 71$ & $2 / 43$ & $1 / 07$ & $1 / 73$ & $1 / 6$ & $4 / 23$ & 8 \\
\hline
\end{tabular}

Source: authors, 2016.

In the second step, after formation of the status quo matrix, in order to normalize the status quo matrix, in itially criteria are weighted. In this study, Shannon Entropy was used for weighting.

According to table (6), the index of accessing to primary school (score: 0.081) with a considerable difference rather other indexes has a higher importance. It includes the most important need of the people living in the deteriorated fabric areas. Accessing to primary schools is followed by the lack of police patrols, which it shows 
that although crime rate is high in these areas, residents are not satisfied of on-time presence of police officers. Another step is accessing to groceries for which there is not an acceptable content. In general, the average value of each index was measured. Therefore, the index of access to services (accessing primary schools, kindergartens, guidance schools, high schools, day nurseries, libraries, sport gyms, bus stations, groceries, healthcare centers, post offices and pharmacies) with the score of 0.304 was ranked first. The main cause for such condition was concentration of urban facilities at south and southwestern parts of the city in which the most educational, sports, official and recreational centers of the city are located; while the deteriorated fabric of the Zahedan city are deprived from such services because of its marginal location rather them. Physical index (g reen space, number of rooms, proper walkways for disabled people, open yards and roofs, residential unit, building size, housing condition in terms of warming and cooling equipments, quality of communication network, lighting of the residential unit, quality of housing in terms of materials, car traffic density, walkways condition) with the score of 0.118 was ranked second. It was due to the old nature of most areas and lack of construction engineering principles in such areas and lack of proper renovation and revitalization of such areas. Social index (violen ce rate in neighborhood, security during walking, drug abuse, robbery, children's security during playing, on -time presence of police forces) with the score of 0.99 was ranked third. Since some deteriorated areas are located at the center and some are in marginal part of the city, the relative distribution among such elements is low. And finally, the environmental index (quality of drinking water, wastewater system, garbage collection, environment's sanitary, surface water disposal and noise pollution) with the score of 0.083 was ranked fourth, which it shows that various areas of Zahedan have a similar level in terms of environ mental considerations rather other indexes.

Table 6. Weight criteria derived from the Shannon entropy

\begin{tabular}{|c|c|c|c|c|c|c|c|c|c|}
\hline Rank & Weight & $z$ & Criterion & Row & Rank & Weight & $z$ & Criterion & Row \\
\hline 12 & $0 / 016$ & + & green space & 20 & 5 & $0 / 030$ & + & Access to the library & 1 \\
\hline 14 & $0 / 013$ & + & $\begin{array}{l}\text { Access to sport } \\
\text { facilities }\end{array}$ & 21 & 13 & $0 / 015$ & + & $\begin{array}{c}\text { Access to } \\
\text { Kindergarten }\end{array}$ & 2 \\
\hline 19 & $0 / 007$ & - & Traffic & 22 & 1 & $0 / 081$ & + & Access to school & 3 \\
\hline 3 & $0 / 052$ & + & $\begin{array}{l}\text { Access to the } \\
\text { retail }\end{array}$ & 23 & 11 & $0 / 017$ & + & Access to schools & 4 \\
\hline 22 & $0 / 004$ & + & $\begin{array}{l}\text { Heating and } \\
\text { Cooling }\end{array}$ & 24 & 4 & $0 / 032$ & + & Access to high school & 5 \\
\hline 15 & $0 / 010$ & + & sewage disposal & 25 & 6 & $0 / 025$ & + & $\begin{array}{l}\text { Access to special } \\
\text { centers }\end{array}$ & 6 \\
\hline 10 & $0 / 018$ & + & Network of streets & 26 & 24 & $0 / 002$ & + & Access to the mosque & 7 \\
\hline 19 & $0 / 007$ & + & $\begin{array}{l}\text { Satisfaction with } \\
\text { sidewalks }\end{array}$ & 27 & 21 & $0 / 005$ & + & Access to Pharmacy & 8 \\
\hline 21 & $0 / 005$ & + & $\begin{array}{l}\text { Access to the bus } \\
\text { stop }\end{array}$ & 28 & 16 & $0 / 009$ & + & Access to health care & 9 \\
\hline 23 & $0 / 003$ & + & Building size & 29 & 20 & $0 / 006$ & - & drug use & 10 \\
\hline 23 & $0 / 003$ & + & $\begin{array}{l}\text { Building consent } \\
\text { of open spaces }\end{array}$ & 30 & 14 & $0 / 013$ & + & Environmental Health & 11 \\
\hline 15 & $0 / 010$ & + & $\begin{array}{l}\text { Quality building } \\
\text { materials }\end{array}$ & 31 & 7 & $0 / 024$ & + & $\begin{array}{c}\text { Drinking Water } \\
\text { Quality }\end{array}$ & 12 \\
\hline 15 & $0 / 010$ & + & $\begin{array}{l}\text { Satisfaction with } \\
\text { housing units }\end{array}$ & 32 & 18 & $0 / 008$ & + & $\begin{array}{l}\text { The safety of children } \\
\text { when playing }\end{array}$ & 13 \\
\hline 15 & $0 / 010$ & + & $\begin{array}{l}\text { The satisfaction of } \\
\text { a number of } \\
\text { rooms }\end{array}$ & 33 & 20 & $0 / 006$ & + & Lighting the night & 14 \\
\hline 23 & $0 / 003$ & + & $\begin{array}{l}\text { The satisfaction of } \\
\text { a residential } \\
\text { neighborhood }\end{array}$ & 34 & 10 & $0 / 018$ & + & $\begin{array}{l}\text { Access to Post } \\
\text { Offices }\end{array}$ & 15 \\
\hline 8 & $0 / 022$ & + & $\begin{array}{l}\text { Suitable sidewalks } \\
\text { for the disabled }\end{array}$ & 35 & 9 & $0 / 019$ & + & $\begin{array}{c}\text { Surface water } \\
\text { disposal }\end{array}$ & 16 \\
\hline 18 & $0 / 008$ & & Pollution Noise & 36 & 16 & $0 / 009$ & + & Garbage collection & 17 \\
\hline 19 & $0 / 007$ & - & $\begin{array}{c}\text { Theft in the } \\
\text { neighborhood }\end{array}$ & 37 & 2 & $0 / 055$ & + & Police presence & 18 \\
\hline 20 & $0 / 006$ & - & $\begin{array}{l}\text { Violence in the } \\
\text { neighborhood }\end{array}$ & 38 & 11 & $0 / 017$ & + & $\begin{array}{c}\text { Security when } \\
\text { walking }\end{array}$ & 19 \\
\hline
\end{tabular}

Source: authors, 2016. 


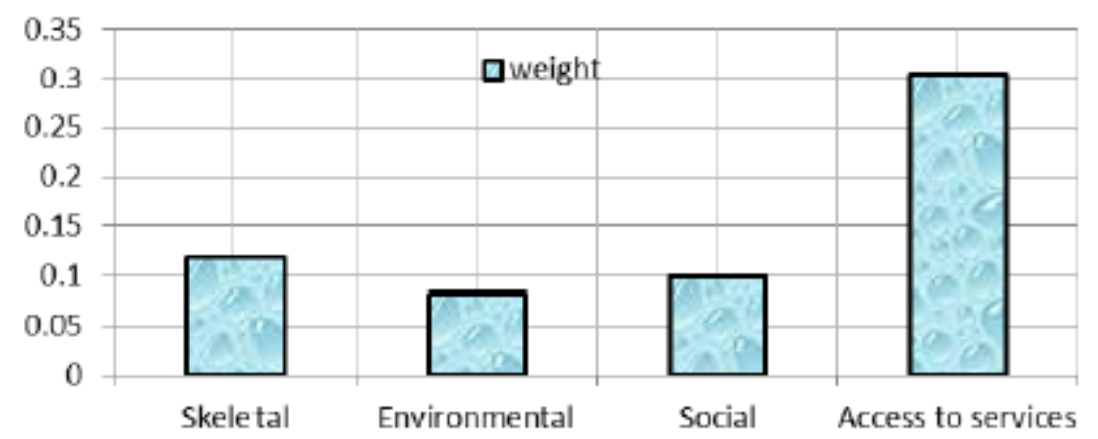

Chart 2. The importance of each of the indicators in the areas of Damaged Area

Source: authors, 2016.

In the third phase, after calculating the weight of criteria, the status quo matrix is normalized using the following equation:

$$
d i j=\frac{q i}{\sum_{j=1}^{n} x i j} x i j
$$

Table 7. Matrix normalized

\begin{tabular}{|c|c|c|c|c|c|c|c|c|c|c|c|c|c|c|c|c|c|c|c|}
\hline & & & & & 114 & 13 & 12 & 811 & $\mathrm{X} 10$ & $\mathrm{X} 9$ & $\mathrm{X} 8$ & $\mathrm{X} 7$ & $\mathrm{X} 6$ & $\mathrm{X} 5$ & $\mathrm{X} 4$ & $\mathrm{X} 3$ & $\mathrm{X} 2$ & $\mathrm{Xl}$ & Are: \\
\hline 1004 & & 001 & $\overline{002}$ & & & 0,1 & 0,002 & 0,002 & 0,001 & $0 / 001$ & 0,001 & 0 & 0,002 & 0,002 & $\overline{0 / 002}$ & $\overline{0011}$ & $0 / 002$ & $0 / 002$ & 1 \\
\hline 1002 & 1068 & 1001 & $/ 003$ & $\overline{0.002}$ & $0 / 001$ & $0 / 001$ & 0,002 & $0 / 002$ & 0 & $0 / 001$ & 0,001 & & 0,002 & 0,003 & 001 & 2008 & 1001 & 1003 & 2 \\
\hline 002 & 053 & 001 & 002 & $0 / 003$ & $0 / 001$ & $0 / 001$ & 0,002 & 0,002 & 0,001 & $0 / 001$ & 0,001 & & 0,003 & 0,006 & $0 / 002$ & $\bar{d} 013$ & 1002 & 1004 & \\
\hline 1001 & 071 & 002 & 004 & $0 / 003$ & $0 / 001$ & 0,001 & 0,005 & 0,003 & 0,001 & $0 / 001$ & 0,001 & $\bar{c}$ & 0,007 & 0,006 & $0 / 003$ & $0 / 012$ & $\overline{0,002}$ & 1005 & \\
\hline $0 / 002$ & 1061 & 0,002 & $0 / 002$ & 0.002 & $0 / 001$ & $0 / 001$ & 0,005 & 0,002 & 0,001 & $0 / 002$ & 0,001 & 0 & 0,003 & 0,007 & $0 / 003$ & $0 / 011$ & $\overline{0.003}$ & $0 / 008$ & \\
\hline $0 / 003$ & 1042 & 0,001 & $0 / 002$ & 0,001 & 0,001 & $0 / 001$ & 0,002 & 0,001 & 0,001 & $0 / 001$ & 0,001 & c & 0,002 & 0,004 & $0 / 002$ & $\overline{0 / 010}$ & 0,002 & $0 / 002$ & \\
\hline 0,002 & 1059 & 0,003 & 0,003 & 0.003 & $0 / 001$ & $0 / 001$ & 0,004 & 0,001 & 0,001 & $0 / 001$ & 0,001 & & 0,002 & 0,002 & $0 / 001$ & $0 / 008$ & $0 / 002$ & 1002 & f \\
\hline 1001 & 1040 & 0,001 & $0 / 001$ & 00002 & 9,001 & $0 / 001$ & 0,002 & 0,001 & 0,001 & $0 / 001$ & 0,001 & & 0,002 & 0,003 & $0 / 002$ & 0,009 & $0 / 002$ & $0 / 004$ & 8 \\
\hline
\end{tabular}

Continuation table (7)

\begin{tabular}{|c|c|c|c|c|c|c|c|c|c|c|c|c|c|c|c|c|c|c|c|}
\hline X38 & X37 & $\mathrm{X} 36$ & X35 & X34 & X33 & X32 & X31 & X30 & $\mathrm{X} 29$ & X28 & X27 & X26 & X25 & X24 & $\mathrm{X} 23$ & $\mathrm{X} 22$ & $\mathrm{X} 21$ & $\mathrm{X} 20$ & Ares \\
\hline 0,001 & $0 / 001$ & 0,001 & 0,001 & 0 & $0 / 001$ & 0,001 & 0,001 & 0 & 0 & 0,003 & $0 / 001$ & 0,002 & 0,001 & 0,001 & 0,004 & $0 / 001$ & 0,001 & 0,001 & 1 \\
\hline 0,001 & $0 / 001$ & 0,001 & $0 / 001$ & 0 & $0 / 002$ & 0,002 & 0,002 & C & c & 0,004 & $0 / 001$ & 0,002 & 0,001 & $0 / 001$ & $0 / 004$ & $0 / 001$ & $0 / 001$ & 0,002 & \\
\hline 0,0001 & $0 / 001$ & 0,001 & $0 / 001$ & 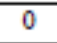 & $0 / 001$ & 0,001 & 0,001 & 8 & 0 & 0,004 & $0 / 001$ & 0,002 & 0,001 & $0 / 001$ & 0,012 & $0 / 001$ & 0,001 & 0,002 & \\
\hline 0,001 & $0 / 001$ & 0,001 & $0 / 001$ & 0 & $0 / 002$ & 0,001 & 0,002 & 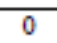 & 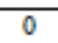 & 0,005 & $0 / 001$ & 0.004 & 0,002 & $0 / 001$ & 0,016 & $0 / 001$ & 0,003 & 0,003 & 4 \\
\hline 0,001 & $0 / 001$ & 0,001 & 0,001 & 0 & $0 / 001$ & 0,001 & 0,001 & 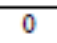 & 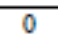 & 0,002 & $0 / 001$ & 0,003 & 0,001 & $0 / 001$ & 0,004 & $0 / 001$ & 0,002 & 0,001 & 5 \\
\hline 0,001 & $0 / 001$ & 0,001 & 0,001 & 0 & $0 / 001$ & 0,001 & 0,001 & 0 & 0 & 0,002 & $0 / 001$ & 0,002 & $0 / 001$ & 0,001 & 0,004 & $0 / 001$ & 0,001 & 0,003 & 6 \\
\hline 0,001 & $0 / 001$ & 0,001 & 0,001 & 0 & $0 / 001$ & 0,001 & 0,001 & 0 & 0 & 0,002 & $0 / 001$ & 0,002 & 0,001 & 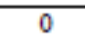 & 0,005 & $0 / 001$ & 0,002 & 0,001 & 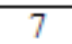 \\
\hline 0,001 & $10 / 00$ & 0,001 & $0 / 001$ & 0 & $0 / 001$ & 0,001 & 0,001 & 0 & 0 & 0,002 & $0 / 001$ & 0,001 & $0 / 001$ & 0 & 0,005 & $0 / 001$ & 0,001 & 0,003 & 8 \\
\hline
\end{tabular}

Source: authors, 2016.

In the fourth phase, after normalizing the criteria, $\sum \boldsymbol{s} \boldsymbol{j}^{+}$and $\sum \boldsymbol{s} \boldsymbol{j}^{-}$are calculated. To do so, for each choice positive and negative indexes are calculated, separately.

In the fifth phase, $\mathrm{QJ}$ is calculated based on positive and negative criteria through the follo wing equation:

$$
Q_{j}=S j^{+}+\frac{S_{\text {min }}^{-} \sum_{j}^{n}=1 S_{j}^{-} x}{S_{j}^{-} \sum_{j}^{n}=1 \frac{S_{\min }^{-}}{S_{j}^{-}}}=S_{j}^{+}+\frac{\sum_{j}^{n}=1 S_{j}^{-}}{S_{j}^{-} \sum_{j}^{n}=1 \frac{1}{S_{j}}}
$$


Final phase: in this phase, the alternative which has the best status among other criteria. The higher the Qj of a choice, its $\mathrm{N}_{\mathrm{j}}$ will be higher, too. It is implied as percentage, it means that its total sum is calculated from 0 to 100 .

$$
N_{j}=\frac{Q_{j}}{Q_{\max }} \times 100
$$

Ranking is conducted based on $Q_{J}$ value; it means that areas with the highest value of $Q_{j}$ and $N_{j}$ have the highest quality of life. As table (4) shows district 4 has the best quality of life.

Table 8 . The results of the model Kopras

\begin{tabular}{|c|c|c|c|c|c|}
\hline Rank & $\mathrm{Nj}$ & $\mathrm{Qj}$ & $\mathrm{Sj}$ & $\mathrm{Sj}^{+}$ & Area \\
\hline 7 & $57 / 50$ & $0 / 099$ & $0 / 004$ & $0 / 112$ & 1 \\
\hline 3 & $75 / 95$ & $0 / 131$ & $0 / 003$ & $0 / 126$ & 2 \\
\hline 4 & $75 / 60$ & $0 / 130$ & $0 / 005$ & $0 / 127$ & 3 \\
\hline 1 & 100 & $0 / 172$ & $0 / 005$ & $0 / 169$ & 4 \\
\hline 2 & $81 / 30$ & $0 / 140$ & $0 / 005$ & $0 / 137$ & 5 \\
\hline 5 & $67 / 63$ & $0 / 117$ & $0 / 004$ & $0 / 095$ & 6 \\
\hline 6 & $67 / 39$ & $0 / 116$ & $0 / 004$ & $0 / 112$ & 7 \\
\hline 8 & $54 / 72$ & $0 / 094$ & $0 / 003$ & $0 / 089$ & 8 \\
\hline
\end{tabular}

Source: authors, 2016.

Ranking areas using life quality indexes and urban capitas and comparing them

In this step, various areas of the deteriorated fabric areas were ranked by COPRAS model based on distribution of urban capita and life quality indexes. As a result, district 4 ranked first based on the urban capitas; it also ranked first in terms of life quality indexes.

Table 9. Ranked dead tis sue areas with urban per capita and quality of life

\begin{tabular}{|c|c|c|c|c|c|c|}
\hline $\begin{array}{c}\text { Rank } \\
\text { capita }\end{array}$ & $\mathrm{Nj}$ & $\mathrm{Qi}$ & $\begin{array}{c}\text { Rating the } \\
\text { quality of life }\end{array}$ & $\mathrm{Nj}$ & Qi & Area \\
\hline 6 & $15 / 53$ & $0 / 063$ & 7 & $57 / 50$ & $0 / 099$ & 1 \\
\hline 8 & $6 / 91$ & $0 / 028$ & 3 & $75 / 95$ & $0 / 131$ & 2 \\
\hline 2 & $35 / 37$ & $0 / 143$ & 4 & $75 / 60$ & $0 / 130$ & 3 \\
\hline 1 & 100 & $0 / 403$ & 1 & 100 & $0 / 172$ & 4 \\
\hline 5 & $18 / 34$ & $0 / 074$ & 2 & $81 / 30$ & $0 / 140$ & 5 \\
\hline 7 & $5 / 80$ & $0 / 023$ & 5 & $67 / 63$ & $0 / 117$ & 6 \\
\hline 4 & $27 / 75$ & $0 / 112$ & 6 & $67 / 39$ & $0 / 116$ & 7 \\
\hline 3 & $32 / 87$ & $0 / 132$ & 8 & $54 / 72$ & $0 / 094$ & 8 \\
\hline
\end{tabular}

Source: authors, 2016.

Finally, the results gained from ranks of areas were rated into five rates to find the relationship between urban capita distribution and life quality indexes. The results showed that the relationship between distribution of urban capitas and life quality indexes has been very poor and it demonstrates that life quality is a relative concept. The expectation level of residents of various neighborhoods to their social and economic structure was very different; as low distribution of urban capitas in some areas does not demonstrate that the quality of life is low for residents of such areas. 
Table 10. Level of per capita urban areas based on the old texture and quality of life

\begin{tabular}{|c|c|c|c|}
\hline $\begin{array}{c}\text { The level of } \\
\text { regions }\end{array}$ & Based on quality of life & The urban per capita & $\begin{array}{c}\text { The number of } \\
\text { subscribers }\end{array}$ \\
\hline 1 & 4 & 4 & 1 \\
\hline 2 & 5 & 8,3 & 0 \\
\hline 3 & 3,2 & 7 & 0 \\
\hline 4 & 7,6 & 5,1 & 0 \\
\hline 5 & 1,8 & 6,2 & 0 \\
\hline
\end{tabular}

Source: authors, 2016.

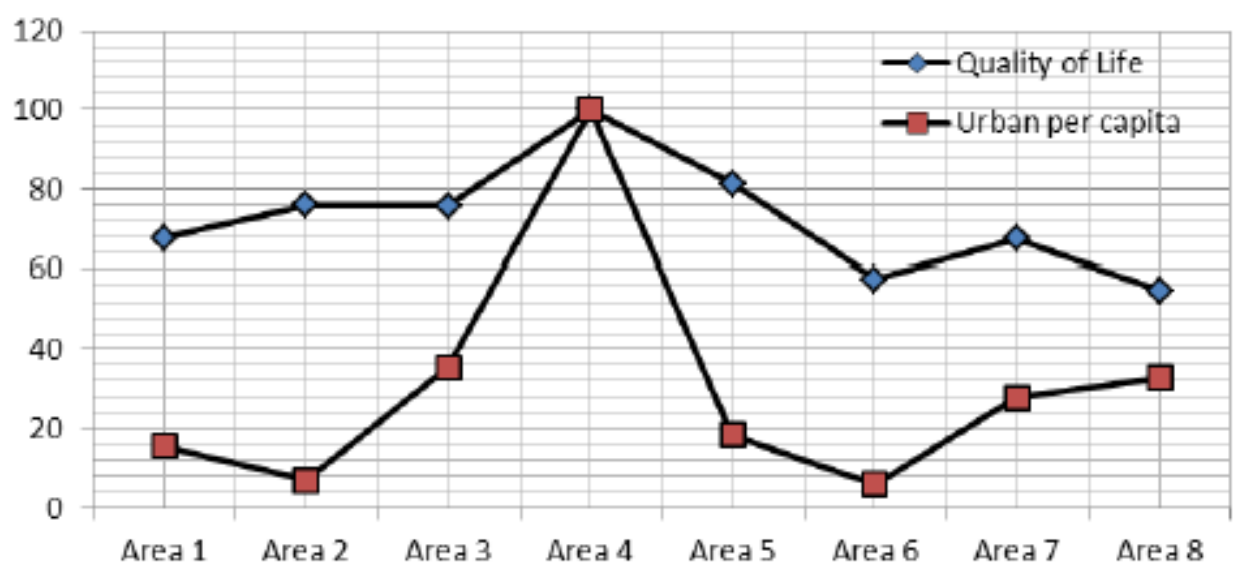

Chart 3. Ranking worn tissue areas based on the quality of life and urban per capita

Source: authors, 2016.

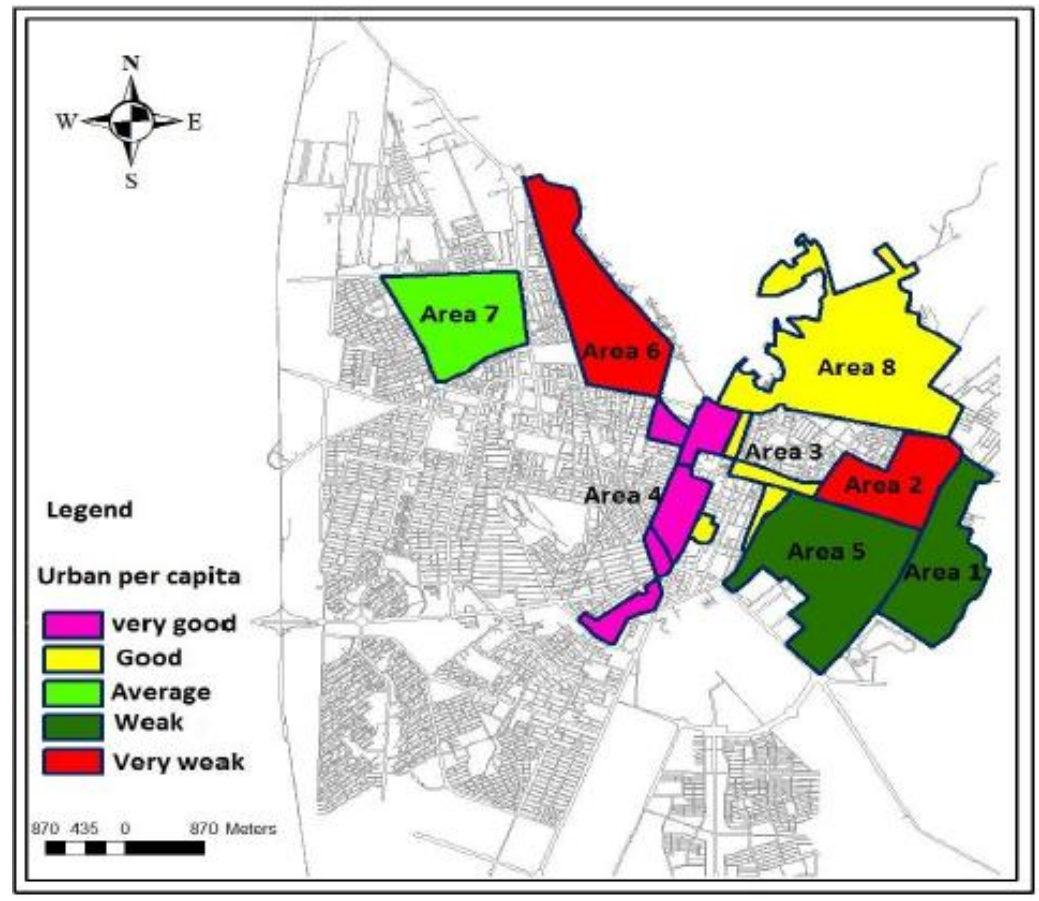

Figure 3. Ran king of areas based on per capita urban distressed areas 


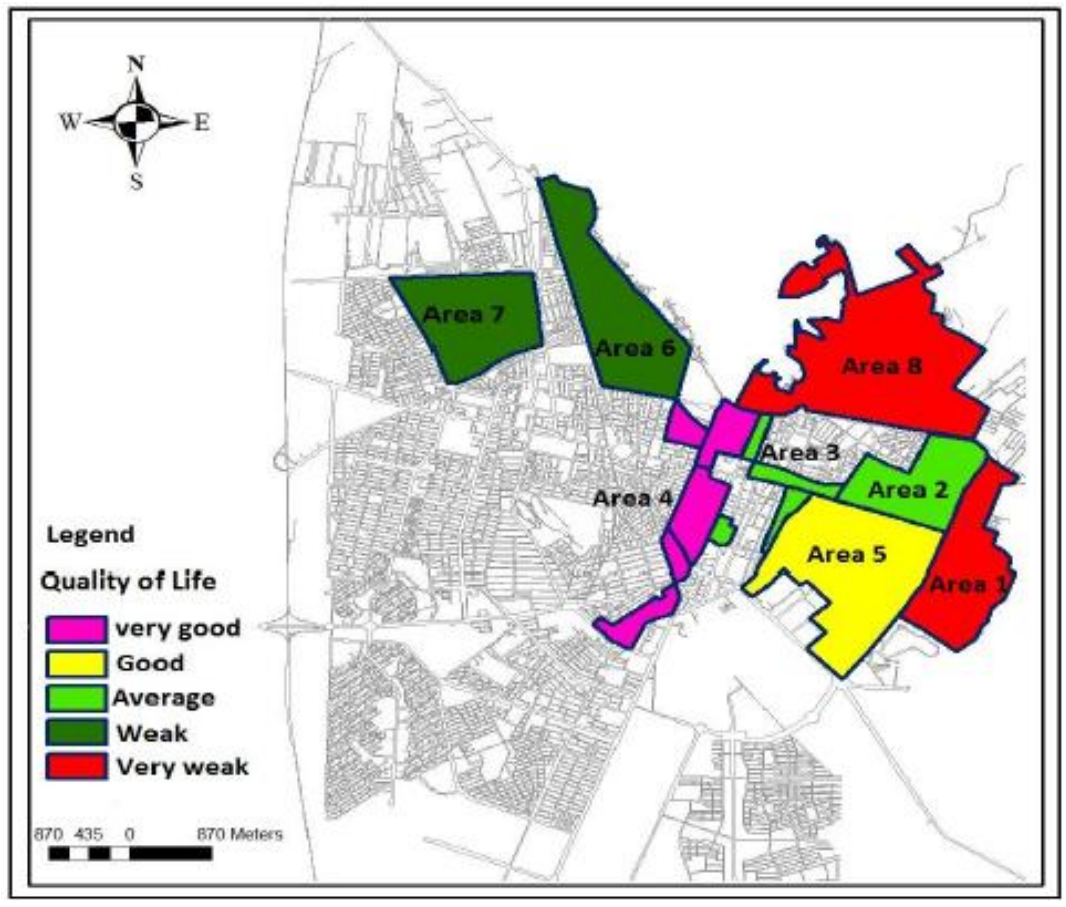

Figure 4. Ranking worn tis sue areas based on the quality of life

The results also show that only district 4 is the first rank either in terms of life quality indexes or capita of functions; whereas, except district 4 there was not any relationship between life quality indexes and city capita in other areas and it indicates that the relationship between distribution of urban capita and life quality indexes is very weak.

\section{Conclusion}

Social justice is a value-based concept which must be analyzed in different social areas and it covers different aspects. The most important causes of human societies' crises in the current era are social inequities which are rooted in the lack of justice and fair in distribution of services and public wealth of the society. Today, fortunately, geographers referring to spatial justice have succeeded to take giant strides to realize fair distribution of interests and public wealth based on certain criteria such as need, merit and public interest. Zahedan City as a major destination for immigrants within recent decades has faced the problem (injustice in distribution of public services). As this increasing trend of population, particularly the urban population, has made unbalanced offering services and has posed social, spatial justice and urban sustainability issues.

Studies show that in the first step of the study, weight of capita across the various areas were achieved using entropy method and except residential and educational capitas which have been distributed in a more fair way across the deteriorated areas, other capitas have shortages which have been distributed unfairly. In the second phase, COPRAS model was used to compare quantity of capitas across various areas with the standard capitas suggested by the Ministry of Housing and Urban Development. Except districts 4, 3, and 5, which even had a better condition rather the standard capita and were closer to the standard capita, other areas of the deteriorated fabric are very different from the standard capita. It demonstrates that distribution and transmittance of urban functions across the deteriorated areas of Zahedan City was unfair and most urban functions have been concentrated in several districts, especially district 4. Deteriorated fabric areas are concentrated mostly in northern and central parts of the city, as central areas have higher capitas.

In the third phase, the life quality across eight districts of the deteriorated fabric of Zahedan City was evaluated through 38 life quality indexes. They were grouped in four classes: physical, social, environ me ntal and access to the urban services. The results of entropy method show that access to primary school is the most significant index and access to mosque is the most insignificant. Gnereally, accessing the urban services is in the first rank, as concentration of urban facilities in southern and southwestern part of Zahedan City has resulted in dissatisfaction of other urban districts, especially its deteriorated fabric of the city.

In the fourth phase, COPRAS Model was used to compare the qualitative level of the various deteriorated 
districts. It was concluded that districts 4,5 , and 2 have the lowest distance from the positive ideal and the most distance to the negative ideal level. Districts $1,3,6,7$ and 8 have the most distance to positive ideal and the most distance to the negative ideal. Finally, to fulfill the project's main purpose, the districts were ranked based on urban capita and life quality indexes. According to the urban capitas, districts 4, 3 and 5 are in higher ranks, while 7, 8, 1, 2, and 6 are in lower ranks. Regarding the life quality indexes, districts 4, 5, and 2 has the highest level, while districts $3,1,7$, and 8 are in the lowest level. It is observed that only district 4 is the first rank in terms of either life quality indexes and functions capita; whereas, there is no relationship between distribution of urban capita and life quality indexes in other districts and it demonstrates that the relationship between distribution of urban capita and life quality indexes has been very weak. Simila lrly, diagram (3) shows that when the function capit is decreased, the life quality has not been declined. These results demonstrate that life quality is a relative concept in which residents' expectation level are different based on their social and economic structure.

\section{Suggestions}

1) Revising the urban management system and avoiding concentration of urban facilities and equipments in the southern and southwestern neighborhoods of the city to which the marginal districts and neighborhoods have no proper access;

2) Simu ltaneous attention to distribution of urban capitas ad life quality level in districts, trying to plan based on local participation and using people's perspective to comprehensive development of districts and avoiding imperative and unilateral planning without considering residents demands and needs;

3) Providing various parts of the city with services must be based on human criteria including needs, merit and priorities including accessing to green space in all districts

4) The most important problem of residents is lack of access to primary schools in the deteriorated fabric of the city. Hence, develop ment of education places must be among the most essential measures of planning for the deteriorated fabric of Zahedan City.

5) Designing and developing a disciplinary network in the deteriorated fabric areas;

6) Reforming and reconstructing water supply network and branches and wastewater system in the deteriorated fabric areas;

7) Organizing functions through forming a reasonable relation between body, spatial organization and functions of the old and new fabric and proper distribution of space and functions.

8) Equipping and preparing deteriorated areas to meet current and future needs of their residents;

9) Integrating and synchronizing related plans of various organizations in order to improve the physical and functional status of the deteriorated fabric and improving their residents' life quality.

\section{References}

Abdi Daneshpour, Z. (2009). Analyzing spatial imbalance in cities.

Afrough, E. (1999). Spaces and social inequity. Press of Modaress University.

Amanpour, S., Alizadeh, H., \& Bagh, S. D. (2013). Development level of Kermanshah counties in terms of enjoying urban services indexes. Amayesh-e Mohit Journal, 23, 106-126.

Antuchviciene, J., Zakarevius, A., \& Zavasdkas, E. K. (2011). Measuring Congruence of Ranking Results Applying Particular MCDM Methods.

Chandra Das, M., Sarkar, B., \& Ray, S. (2012). A framework to measure relative performance of Indian technical institutions using integrated fuzzy AHP and COPRAS methodology. Socio-Economic Planning Sciences, 46, 230-241. http://dx.doi.org/10.1016/j.seps.2011.12.001

Cheng, K., \& Yam, S. (2000). Development of a Fuzzy Multi- criteria Decision Support System for Waste Management, university of Region, saskatchevan.

Devas, N., \& Rakodi, C. R. (1993) planning and managing urban development. In: New approaches to Urban Planning and Management in developing world.

Gray, R. (2002). Social Accounting Project and Accounting Organization and Society Privileging Engagement, Imaging New Accounting Organizations and Society.

Habibi, K., Alizadeh, H., Moradi Masihi, V., Valadbeigi, S., \& Vafaie, S. (2011). Analyzing social justice condition in the spatial structure of Sanandaj City. Armanshahr Journal, 7, 103-112. 
Hafe znia, M. (2012). An overview of research method in humanities. Tehran. Samt Press.

Harvey, D. (1998). Social Justice and city (Hesamiayan F., et al. trans.). Tehran:Processing and urban planning.

Harvey, D. (2000). Social Justice and City. Trans. Farrokh Hesamian and Muhammad Reza Haeri. Tehran. http://dx.doi.org/10.1023/A:1005207320044

Hataminejad, H., Farhoodi, R., \& Jaberi, M. M. (2009). Analyzing social inequity in taking advantage of urban services (case study: Esfarayen). Tehran. Human Geographical Researches Journal, 5.

Hataminejad, H., Manuchehri Miandoab, A., Baharlu, I., Ebrahimpour, A., \& Hatamineja, H. (2012). City and Social Justice: an analysis about regional inequities (Case study: old neighborhoods of Miandoab). Human Geographical studies journal, 80, 41-63.

Kakalocas, N. (2009). Performance evaluation of Turkish cement firms with fuzzy analytic hierarchy process and TOPSIS methods, expert systems with Applications, 36, 702-715.

Kalantari, A., Nasr Esfahani, A., \& Aram, H. (2013). Justice In city. Spatial distribution of facilities and equipments. Tehran.

Kamali, A. (2000). Aprelude on sociology of social inequity. Samt Press. Tehran.

Khoshroi, G. (n.d.). Social Justice and Urban space. National se minar of urban construction.

Kumar Dey, P., Nath Ghosh, D., \& Chand Mondal, A. (2011). A MCDM Approach for Evaluating Bowlers Performance in IPL. Journal of Emerging Trends in Computing and Information Sciences, 2(11).

Maleki, S. (2003). Sustainable city and urban sustainable development. Housing and revolution journal, 102.

Mobaraki, O., \& Abdoli, A. (2013). Analyzing hierarchy of districts of Uromiya based on the urban sustainable development indexes. Social Science Applied Researches, 30, 46-65.

Mulliner, E., Smallbone, K., \& Vida, M. (2012). An assessment of sustainable housing affordability using mu ltip le criteria decision making method, Omega the international Journal of Management Science, p, 1-10.

Pourtaheri, M. (2010). Multi-criteria decision making methods on geography. Samt Press.

Richardson, H. W. (1979). Aggregate Efficiency and Interregional Equity. In H. Folmer (Ed.), Spatial Inequalities and Rigional Development (pp. 161-183). Boston: Kluwer. http://dx.doi.org/10.1007/978-94-017-3046-4_7

Sauj, M., \& Ward, A. (2011). Urban sociology. Trans. Abolghas sem Pourreza. Tehran. Samt Press.

Sharifi, A. (2006). Social justice and city: analyzing regional inequities in Ahwaz City. Tehran University

Sheikhi., M. T. (2001). Urban sociology. Tehran. Enteshar Press.

Shokohi, H. (2000). New perspectives on urban geography. Samt Press.

Sudhira, H. S. et al. (2003). urban growth analysis using spatial temporal data. journal of society of remote sensing, 31. http://dx.doi.org/10.1007/BF03007350

Taghvaie, M., \& Kiomarthi, H. (2011). Rtaing urban neighborhoods based on enjoying urban facilities and services using Topssis technique (case study: neighborhoods of Abadeh City). Urban Research and Planning Journal, 5, 23-42.

Tamin, M. (1994). Classification sociology and social inequity. Trans. Abdolhussein Nik Gohar. Totia Press.

Wang, Y. M., \& Elhag, T. (2007). Fuzzy TOPSIS method based on alpha level sets with an application to bridge risk assessment. Expert Systems with Applications, $31, \quad 309-319$. http://dx.doi.org/10.1016/j.eswa.2005.09.040

Zajda, J., Majhanovich, S., \& Rust, V. (2006). Education and Social Justice.

\section{Copyrights}

Copyright for this article is retained by the author(s), with first publication rights granted to the journal.

This is an open-access article distributed under the terms and conditions of the Creative Commons Attribution license (http://creativecommons.org/licenses/by/4.0/). 